\title{
VERNACULAR RELIGION AND CONTEMPORARY SPIRITUALITIES \\ TRIBUTE TO LEONARD NORMAN PRIMIANO (1957-2021)
}

\section{MARION BOWMAN}

It is now more than a quarter century since Leonard Primiano's seminal article "Vernacular Religion and the Search for Method in Religious Folklife" launched the concept of Vernacular Religion to denote the study of "religion as it is lived: as human beings encounter, understand, interpret, and practice it" (Primiano 1995: 44). Vernacular Religion demands that scholars take seriously the minutiae of how people live their religion in particular contexts, their interaction with material culture, their often flexible attitude to and use of tradition, their frequently complex relationship and negotiations with institutional forms of religiosity, and above all their agency.

This issue of Traditiones brings insights into how people deal with enormous issues such as our place in the universe, our relationship with-other-than human beings, death, apocalypse and afterlives using an 'toolkit' of institutional and vernacular knowledge.

Keywords: vernacular religion, UFO, Leonardo Primiano, tradition
Minilo je že več kot četrt stoletja, odkar je Leonard Primiano $v$ razpravi "Vernakularna religija in iskanje metode za raziskovanje verskega ljudskega življenja" uporabil koncept vernakularne religije za označevanje preučevanja "vere, kakršno se živi: kakor jo ljudje srečajo, razumejo, interpretirajo in izvajajo" (Primiano 1995: 44). Vernakularna religija zabteva, da se raziskovalci resno posvetijo podrobnostim, npr. temu, kako ljudje živijo svojo vero $v$ določenih kontekstih, njihovi interakciji z materialno kulturo, njihovemu pogosto prilagodljivemu odnosu do tradicije in njeni uporabi, pogosto zapletenemu razmerju in pogajanju z institucionalnimi oblikami religioznosti in predvsem njihovi tvornosti.

Ta zvezek Traditiones prinaša poglede na to, kako se ljudje spoprijemajo s pomembnimi vprašanji, npr. o našem mestuv vesolju, o razmerju z drugim, ne-človeškim, nezemeljskim, s smrtjo, apokalipso in posmrtnim življenjem, pri čemer uporabljajo "orodje institucionalnega in domačega znanja. Ključne besede: vernakularna religija, NLP, Leonardo Primiano, tradicija

When this volume was proposed there was no expectation of any sort of memorial aspect to if, but sadly the death of the remarkable scholar Leonard Norman Primiano on 25 July 2021 altered that. The papers in this collection, bringing together some fascinating and significant studies of UFO beliefs, praxis and material culture, as well as contemporary (re)presentations of death, apocalypse and afterlives, to some extent exemplify the broad and vibrant reach of Vernacular Religion, the unexpected contexts in which it might be found, and some of the issues that were central to Leonard's extensive writings on the topic.

It is now more than a quarter century since Leonard Primiano's seminal article "Vernacular Religion and the Search for Method in Religious Folklife" launched the concept of Vernacular Religion to denote the study of "religion as it is lived: as human beings encounter, understand, interpret, and practice it" (Primiano, 1995: 44). As I have noted elsewhere (Bowman, 2022a, 2022b), that article brought about significant refocussing and profound changes in Religious Studies, Folklore Studies and Ethnology as to how we might describe, study, conceptualise and appreciate the messy, complex and creative reality of the ways in which people are religious and 'do religion' in their everyday lives. 
Vernacular Religion as perceived by Leonard is religion per se; it is not merely a synonym for folk religion.

As "an interdisciplinary approach to the study of the religious lives of individuals with special attention to the process of religious belief, the verbal, behavioral, and material expressions of religious belief, and the ultimate object of religious belief" (Primiano, 1995: 44), Vernacular Religion demands that scholars take seriously the minutiae of how people live their religion in particular contexts, their interaction with material culture, their often flexible attitude to and use of tradition, their frequently complex relationship and negotiations with institutional forms of religiosity, and above all their agency. In his Afterword to Vernacular Religion in Everyday Life: Expressions of Belief (Bowman, Valk, 2012), Leonard characterised ambiguity, power, and creativity as hallmarks of vernacular religion, highlighting "the power of the individual and communities of individuals to create and re-create their own religion" (Primiano, 2012a: 384) and asserting that religion as it is lived involves "the continuous art of individual interpretation and negotiation of any number of influential sources" (ibid.).

Leonard had gained a solid academic background in both Religious Studies and Folklore Studies through his BA in Religious Studies (University of Pennsylvania, 1978), Master of Theological Studies (Harvard Divinity School, 1980), MA in Folklore and Folklife (University of Pennsylvania, 1982) and a dual doctorate in Religious Studies and Folklore and Folklife Studies (University of Pennsylvania, 1993). He was therefore in a strong position to act as conceptual and methodological 'bridge' between the two fields. Vernacular Religion, he declared, "challenges religious studies to incorporate the interdisciplinary strengths of folklore/folklife in the study of the religious individual and the significance of religion as it is lived in the contemporary context" (1995: 52). Leonard was instrumental in establishing the Folk Belief and Religious Folklife section of the American Folklore Society (of which he was an elected Fellow), and the Folklore and Religion Seminar of the American Academy of Religion. Of Italian and Polish heritage, Leonard was also very much involved in European scholarship. It is appropriate that one of the authors in this volume is Anders Gustavsson, the first chairman of the Folk Religion commission of SIEF (International Society for Ethnology and Folklore). Leonard and I participated in this group's extraordinary second symposium "Folk Religion: Continuity and Change" in Portugal in 1996, organised by Anders Gustavsson and Maria Santa Montez, which was a hugely significant event for us both. Leonard became a regular at these SIEF events until 2019, leading to strong European academic connections and valued friendships, including his close relationship with Anne Rowbottom whom he met at the splendid third symposium on Politics and Folk Religion organised in 1999 by Gábor Barna in Szeged, and with István and Kinga Povedák.

As many former students have attested since his death, Leonard was an inspirational lecturer at the Roman Catholic Cabrini University (originally Cabrini College) in Radnor, Pennsylvania, where he worked from 1993, eventually serving as Department Chair and 
Professor of Religious Studies there until 2021. He also taught at Memorial University of Newfoundland and the University of Pennsylvania. At conferences too, his papers were lively and thought-provoking; a number of scholars (especially when they were 'careeryoung') report having found them significant for their future academic trajectories, along with his perceptive questions or helpful comments on their papers. He was generous and supportive with his time and knowledge.

Leonard is probably best known for his ground-breaking 1995 article "Vernacular Religion and the Search for Method in Religious Folklife", but there was much more to this remarkable man and his scholarly achievements than this one article. While Leonard initially developed many of his insights on vernacular religion through studying the Philadelphia chapter of the gay and lesbian Roman Catholic organisation Dignity during the AIDS crisis, the topic of his PhD dissertation (Primiano, 2001, 2022a), he continued to write about vernacular religion in a range of contexts until the end of his life. Leonard's passion for and enjoyment of material and visual culture was enormous; he was an inveterate collector (Primiano, 2016a), and he curated numerous exhibitions in addition to writing about diverse aspects of religious materiality. He not only studied vernacular Catholic material culture and the myriad ways in which people utilise, interact with and relate to it (e.g. Primiano, 2007, 2012b, 2015, 2016b), he analysed materiality in relation to the racially diverse, Philadelphia-based community of Father Divine's International Peace Mission Movement with whom he worked closely for many years (e.g. Primiano, 2004, 2014), and the lifeworld revealed in the vibrant hooked rugs of Sister Ann Ameen (Primiano, 2002). Even those familiar with his better-known work on vernacular religion would benefit from revisiting the many articles, chapters and encyclopaedia entries in which he continued to refine his methodological insights and engage with an eclectic range of topics, including American popular culture and media (e.g. Primiano, 1999, 2009). A collection of fourteen of his previously published essays will appear in a posthumously published volume (Primiano, 2022b), edited by a group of American Religion scholars as a tribute to Leonard's contribution to religious studies and folklore studies; other friends and colleagues are working to bring to fruition a number of articles and publications in which he was engaged at the time of his death.

Vernacular religion has broad applicability and relevance, both in relation to more traditional manifestations of institutional religiosity but also to the more fluid forms of contemporary spirituality, beliefs and praxis to emerge in physical and increasingly in online environments. Vernacular religion has been embraced and applied by scholars in relation to a great range of contexts and manifestations (Bowman, Valk, 2012; Valk, Bowman, 2022), from the spiritually diverse town of Glastonbury in England (Bowman, 2000, 2009) to Finnish Judaism (Illman, Czimbalmos, 2020); from former Soviet Secret Police archives (Kapaló, Povedák, 2022) to a Goddess Temple in Assam (Valk, 2019); from Hungarian neo-nationalism (Povedák, 2014, 2020a, 2021a) and Romanian ethno-paganism (Hubbes, Povedák, 2014, 2019) to Estonian dowsing (Kivari, 2016); from contemporary Christian 
rock music (Povedák K., 2017, 2020) to Romani pilgrimages (Povedák, 2020b), to give but a few examples.

While some may have felt that Vernacular Religion underplayed the political and power nuances of religion, Leonard countered that "vernacular religiosity has the potential to manifest dimensions of both confirmation and contestation, of legitimation of the hegemonic as well as resistance to such societal and cultural manifestations of power" (Primiano, 2012: 387). He was also adamant that accentuating individual religious creativity does not detract from the dynamics involved in collective acts of religiosity; rather, it reflects realistically that people constantly interpret and negotiate "any number of influential sources" within particular contexts and in response to a range of resources.

This all brings us back to this issue of Traditiones, where we are given fascinating insights into how people deal with enormous issues such as our place in the universe, our relationship with-other-than human beings, death, apocalypse and afterlives using an enormous 'toolkit' of institutional and vernacular knowledge, images and ideas. Anders Gustavsson (2021) continues his long-term research on death and afterlife beliefs in Scandinavia (Gustavsson, 2011), revealing continuity and change in how traditional ideas are being adapted; the influence of New Age ideas in reducing the prominence of judgement at end of life and the assumption of positive and inclusive post-life futures; the role of the internet as a forum for the expression and visual portrayal of such ideas; and the extent to which such developments appear to be occurring at different rates between Sweden and Norway. Daniel Wojcik (2021) provides a thorough overview of 'paleoastronautic' mythologies of alien intervention in human history, and case studies of a number of UFO religious groups, highlighting the importance of broader scientific and socio-political contexts and the ongoing influence and reworking of apocalyptic and millennialist ideas in the production of worldviews and representations of aliens - and by extension, ourselves. István Povedák's pioneering article (2021b) tackles a hitherto comparatively neglected field in relation to UFO 'culture', its artistic and material dimensions. Studying a range of visual and material artefacts, this piece provides fascinating insights into the influences, creativity, mythology and praxis of those involved in physically expressing UFO-inspired worldviews, and the wealth of information to be gleaned from focussing attention on them. In his fascinating comparison of Christian Millennialist and New Age digital environments in relation to 2012, László Attila Hubbes (2021) again draws our attention to visual culture, this time highlighting the images circulating online and the extent to which traditional tropes and imaginaries are fluidly rewoven, reworked and sometimes shared in these notionally very different cyber contexts. In all these cases, individuals' and groups' creative employment and manipulation of visual imagery and ideas drawn from diverse sources can be both powerful and empowering, comforting and deeply disconcerting, building and maintaining lifeworlds, reflecting both the importance of visual and material culture, and "the power of the individual and communities of individuals to create and re-create their own religion" (Primiano, 2012: 384). 
In 2006 Leonard was diagnosed with oesophageal cancer, a cruel blow for such a passionate teacher and vibrant communicator. For the next 15 years his friends and colleagues were amazed and delighted as Leonard's joie de vivre, his energy and enthusiasm, his sense of fun and his considerable capacity for friendship, his resilience and his dogged determination to get through some immensely difficult health challenges appeared to continue unabated; even his electronic voice somehow could not mask his enormous personality. Since his death, numerous tributes have been paid online and in publications by former students, colleagues, friends, those who met him fleetingly and those who knew him through his writing. I first met Leonard in the summer of 1995, when we were both conducting fieldwork in Newfoundland, and immediately became firm friends. Like me, many have benefitted not just from Leonard's remarkable depth and breadth of knowledge, but from the joy of knowing a truly remarkable man.

While there are more collections in progress to remember and tribute the work of Leonard Norman Primiano, the current issue of Traditiones is the first in the line. This collection of articles is a result of the ERC CZ project no. LL2006 ("ReEnchEu") funded by the Czech Ministry of Education, Youth, and Sport and headed by Alessandro Testa at the Department of Sociological Studies, Faculty of Social Sciences, Charles University in Prague.

\section{REFERENCES}

Bowman, Marion. 2022a. In Memoriam Leonard Norman Primiano (1957-2021). Folklore 13. DOI: https:// doi.org/10.1080/0015587X.2021.2008143. (in print)

Bowman, Marion. 2022b. Afterword: 25 Years of Vernacular Religion Scholarship. In Vernacular Knowledge: Contesting Authority, Expressing Beliefs, eds. Ülo Valk and Marion Bowman. Sheffield: Equinox. https://api.equinoxpub.com/books/2174.

Bowman, Marion. 2000. More of the Same? Christianity, Vernacular Religion and Alternative Spirituality in Glastonbury. In Beyond New Age: Exploring Alternative Spirituality, eds. Steven Sutcliffe and Marion Bowman, 83-104. Edinburgh: Edinburgh University Press.

Bowman, Marion. 2009. From Glastonbury to Hungary: Contemporary Integrative Spirituality and Vernacular Religion in Context. In Passageways. From Hungarian Ethnography to European Ethnology and Sociocultural Anthropology, ed. Gábor Vargyas, 195-221. Budapest: Department of European Ethnology and Cultural Anthropology, The University of Pécs - L'Harmattan Publishing House.

Bowman, Marion, and Ülo Valk, eds. 2012. Vernacular Religion in Everyday Life: Expressions of Belief. Sheffield, Bristol: Equinox Publishing.

Gustavsson, Anders. 2011. Cultural studies on death and dying in Scandinavia. Oslo: Novus.

Gustavsson, Anders. 2021. Faith, Death and the Internet in Norway and Sweden. Traditiones 50 (3): DOI: https://doi.org/10.3986/Traditio2021500305.

Hubbes, László Attila. 2019. The Re-Paganisation of Christian Symbolism. In Expressions of Religion: Ethnography, Performance, Visual, eds. István Povedák, Eugenia Roussou and Clara Saraiva, 241-295. Berlin: Lit-Verlag. 
Hubbes, László Attila. 2021. Recombinant Revelations: 2012 in Millenarian and New Age Cyber-Apocalypticism: Discourse Analysis of the Symbolism and Visual Rhetoric in Two Digital Environments Predicting 2012-Apocalypse. Traditiones 50 (3). DOI: https://doi.org/10.3986/Traditio20215004.

Hubbes, László Attila, and István Povedák. 2014. Ethno-paganism as a Placebo-effect for Identity Reconstruction Processes in Hungary and Romania? Religiski. Filozofiski Raksti (17): 133-152.

Illman, Ruth, and Mercédesz Czimbalmos. 2020. Knowing, Being, and Doing Religion: Introducing an Analytical Model for Researching Vernacular Religion. Temenos 56 (2): 171-199. DOI: https:// doi.org/10.33356/temenos.97275.

Kapaló, James A., and Kinga Povedák. 2022. Reframing Religious Underground. In The Secret Police and the Religious Underground in Communist and Post-Communist Eastern Europe, eds. James A. Kapaló and Kinga Povedák, 1-36. New York, Abingdon: Routledge.

Kivari, Kristel. 2016. Dowsing as a Link Between Natural and Supernatural: Folkloristic Reflections on Water Veins, Earth Radiation and Dowsing Practice. Dissertationes Folkloristicae Universitatis Tartuensis 24. Tartu: University of Tartu Press.

Povedák, István. 2014. MOGY. A Vessel Ritual in Post-Socialist Hungary. Traditiones 41 (1): 147-158. DOI: https://doi.org/10.3986/Traditio2012410113.

Povedák, István. 2020a. The Religious Neo-nationalism in Hungary. In Religion, Populism, Neonationalism, eds. Florian Höhne and Torsten Meireis, 289-308. Berlin. DOI: https://doi. org/10.5771/9783748905059-291.

Povedák, István. 2020b. 'Give me some beautiful holy images that are colorful, play music, and flash!' The Roma Pilgrimage to Csatka. Journal of Global Catholicism 4 (2): 36-67. DOI: https://doi. org/10.32436/2475-6423.1075.

Povedák, István. 2021a. 'Come, look and hear how the past has been and the future will be!' Festival Culture and Neo-Nationalism in Hungary. In Festival Cultures. Mapping New Fields in the Arts and Social Sciences, eds. Maria Nita and Jeremy H. Kidwell. Springer. [in print]

Povedák, István. 2021b. The Artistic and Material Dimension of UFO Culture. Traditiones 50 (3). DOI: https://doi.org/10.3986/Traditio2021500303.

Povedák, Kinga. 2017. Hillsongization, Religious Ecumenism, and Uniformity: A Hungarian Case Study. In The Hillsong Movement Examined: You Call Me Out Upon The Waters, eds. Tania Riches and Thomas Wagner, 181-198. Cham: Palgrave Macmillan.DOI: https://doi.org/10.1007/978-3-319-59656-3_10.

Povedák, Kinga. 2020. Rockin' the Church: Vernacular Catholic Musical Practices. Journal of Global Catholicism 4 (1): 42-63. DOI: https://doi.org/10.32436/2475-6423.1066.

Primiano, Leonard Norman. 1995. Vernacular Religion and the Search for Method in Religious Folklife. Western Folklore 54 (1): 37-56. DOI: https://doi.org/10.2307/1499910.

Primiano, Leonard Norman. 1999. The Vernacular Religious Character of American Television: Continuity and Change in Media Representations of the Supernatural. In Folk Religion: Continuity and Change, eds. Anders Gustavsson and Maria Santa Vieira Montez, 311-322. Lisbon: Universidade Nova de Lisboa; Uppsala: Etnologiska Institutionen, Uppsala Universitet.

Primiano, Leonard Norman. 2001. What is Vernacular Catholicism? The "Dignity" Example. Acta Ethnographica Hungarica 46 (1-2): 51-58. DOI: https://doi.org/10.1556/AEthn.46.2001.1-2.6.

Primiano, Leonard Norman. 2002. Textures of a Religious Life: The Vernacular Religious Art of Sister Ann Ameen. In Art and the Religious Impulse, Bucknell Review, ed. Michael Eric Mazur, 62-83. Lewisburg: Bucknell University Press.

Primiano, Leonard Norman. 2004. Bringing Perfection in these Different Places: Father Divine's Vernacular Architecture of Intention. Folklore 115: 13-26. DOI: https://doi.org/10.1080/0015587042000192501. 
Primiano, Leonard Norman. 2007. The Vow As Visual Feast: Honoring St. Joseph in Sicilian American Homes. Traditiones 36 (1): 113-125. DOI: https://doi.org/10.3986/Traditio2007360108.

Primiano, Leonard Norman. 2009. "For What I Have Done and What I Have Failed to Do": Vernacular Catholicism and The West Wing. In Small Screen, Big Picture: Television and Lived Religion, eds. Diane Winston, 99-123. Waco: Baylor University Press.

Primiano, Leonard Norman. 2012a. Afterword - Manifestations of the Religious Vernacular: Ambiguity, Power and Creativity. In Vernacular Religion in Everyday Life: Expressions of Belief. Sheffield, eds. Marion Bowman and Ülo Valk, 382-394. Bristol, Equinox Publishing.

Primiano, Leonard Norman. 2012b. Catholiciana Unmoored: Catholic Ex-Votos in Catholic Tradition and their Commercialization as Religious Commodities. In Graces Received: Painted and Metal Ex-Votos from Italy. The Collection of Leonard Norman Primiano, eds. Rosangela Briscese and Joseph Sciorra, 9-37. New York, John D. Calandra Italian American Institute.

Primiano, Leonard Norman. 2014. 'And as we dine. We sing and praise God': Mother Divine's Theology of Food. In Religion, Food, and Eating in North America, eds. Ben Zeller, Marie Dallam and Nora Rubel, 42-67. Columbia, Columbia University Press.

Primiano, Leonard Norman. 2015. Kitsch. In The Routledge Companion to Religion and Popular Culture, eds. Eric Michael Mazur and John C. Lyden, 281-312. London: Routledge.

Primiano, Leonard Norman. 2016a. Collecting Vernacular Religious Material Culture. Material Religion 12 (3): 381-383. DOI: https://doi.org/10.1080/17432200.2016.1192157.

Primiano, Leonard Norman. 2016b. Artifacts of Belief: Holy Cards in Roman Catholic Culture. In Experiencing Religion: New Approaches to Personal Religiosity, eds. Clara Saraiva et al., 119-142. Berlin: Lit-Verlag.

Primiano, Leonard Norman. 2022a. “The Upper Room”: Domestic Space, Vernacular Religion, and the Observant University Catholic. In Vernacular Knowledge: Contesting Authority, Expressing Beliefs, eds. Ülo Valk and Marion Bowman. Sheffield: Equinox. [in print]

Primiano, Leonard Norman. 2022b. Vernacular Religion: Collected Essays of Leonard Norman Primiano, ed. Deborah Dash Moore. New York: New York University Press

Valk, Ülo. 2019. Shrines, Stones, and Memories: the Entangled Storyworld of a Goddess Temple in Assam. In South Asian Folklore in Transition: Crafting New Horizons, eds. Frank J. Korom and Leah K. Lowthorp, 105-119. London, New York: Routledge, Taylor \& Francis Group.

Wojcik, Daniel. 2021. UFO Mythologies: Extraterrestrial Cosmology and Intergalactic Eschatology. Traditiones 50 (3). DOI: https://doi.org/10.3986/Traditio2021500302.

\section{VERNAKULARNA RELIGIJA IN IN SODOBNE DUHOVNOSTI: V SPOMIN LEONARDU NORMANU PRIMIANU (1957-2021)}

Minilo je že več kot četrtstoletja, odkarje Leonard Primiano v razpravi "Vernakularna religija
in iskanje metode za raziskovanje verskega ljudskega življenja" uporabil koncept vernakularne
religije za označevanje preučevanja "vere, kakršno se živi: kakor jo ljudje srečajo, razumejo,
interpretirajo in jo izvajajo" (Primiano 1995: 44). Vernakularna religija zahteva, da se 
raziskovalci resno posvetijo podrobnostim, npr. temu, kako ljudje živijo svojo vero $v$ določenih kontekstih, interakciji z materialno kulturo, njihovemu pogosto prilagodljivemu odnosu do tradicije in njeni uporabi, pogosto zapletenemu razmerju in pogajanju z institucionalnimi oblikami religioznosti in predvsem njihovi tvornosti.

Primiano je v sklepni besedi knjige Vernacular Religion in Everyday Life: Expressions of Belief kot pomembne znake vernakularne religije označil dvoumnost, moč in ustvarjalnost, pri čemer je poudaril "moč posameznika in skupnosti, da ustvarjajo in ponovno ustvarijo svojo lastno religijo". Religija, kakršna se živi, vključuje "neprekinjeno umetnost individualne interpretacije in pogajanja o poljubnem številu vplivnih virov. "Po njegovem mnenju vernakularna religija izziva študije religije in od njih terja interdisciplinarnost pri preučevanju verujočega posameznika in pomena religije v sodobnem kontekstu.

Pomemben pa je še en vidik, kjer se kaže potencial vernakularne religioznosti, to je tako legitimacija hegemonije kot tudi odpor do takšnih družbenih in kulturnih manifestacij moči.

Ta zvezek Traditiones prinaša poglede na to, kako se ljudje spoprijemajo s pomembnimi vprašanji, npr. o našem mestu v vesolju, o razmerju z drugim, ne-človeškim, nezemeljskim, $s$ smrtjo, apokalipso in posmrtnim življenjem, pri čemer uporabljajo "orodje« institucionalnega in domačega znanja.

Dr. Marion Bowman, The Open University, Walton Hall, Milton Keynes, marion.bowman@open.ac.uk 